\title{
The People: Where Will They Go?
}

\section{John Sturzaker}

At times of profound challenge to established ways of doing things, it can be helpful to return to first principles and ask what we (think we) are trying to achieve through any given endeavour. In the case of planning, we can return to one of the foundation stones of the discipline and profession - Ebenezer Howard's 1898 To-Morrow: A Peaceful Path to Real Reform. The title of this Viewpoint is drawn from Howard's Three Magnets diagram (see Figure 1). The Town-Country magnet in this diagram summarises Howard's views of the benefits of the Garden City, i.e. a form of urban development which combined the advantages of both the town and the country, but excluded their disadvantages.

[INSERT FIGURE 1 HERE]

Figure 1 - The Three Magnets

Source: Howard (1898, p. 8)

Key parts of the Town-Country magnet which are particularly pertinent in the age of selfdistancing and social isolation are 'Beauty of Nature; Fields and Parks of Easy Access; Bright Homes \& Gardens'. At the time of writing in the UK, we are yet to see the peak of the virus, and are under a state of "lockdown". The UK Government's swiftly introduced legislation requires 'people to stay at home, except for very limited purposes'... and stops 'all gatherings of more than two people in public' (Cabinet Office, 2020, p. 1). The 'very limited purposes' for which people are allowed to leave home include 'one form of exercise a day... alone or with members of your household' (ibid.). These measures are being enforced where necessary by the police, who in most cases have interpreted them to mean that people must not travel by car to beaches, national parks or other places where the 'Beauty of nature' can be experienced (Pidd \& Dodd, 2020). Strict limits on travel have also been adopted in urban areas 'to make sure drivers are sticking to lockdown rules' (Thomas, 2020). The benefits, therefore, of Howard's 'Fields and Parks of Easy Access' and/or 'Bright Homes \& Gardens' have suddenly become of critical importance to many, who are no longer able to travel further afield to access open space. Whilst in most cases this is not, as it was in the late $19^{\text {th }}$ and early $20^{\text {th }}$ centuries, a matter of life and death, there is emerging evidence that virus transmission is highest in the most overcrowded areas of the UK (Kenway \& Holden, 2020).

In this Viewpoint I reflect upon long-term trends towards higher density (residential) development in the UK, the impacts these trends may have had on the transmission, and attempts to avoid further spread, of Covid-19; and whether in the longer term residential preferences, and planning policy, may (need to) change. As with the other Viewpoints in this special issue it is, of course, speculative and based on data which is still emerging - the latter in most cases having not been subject to the rigour of peer review.

\section{The People: Where (and How) Do They Live Now?}

Early research has shown that deprivation and overcrowding have statistically significant effects on the number of Covid-19 cases, suggesting that 'the standards which have come to determine what constitutes adequate housing now need to be abandoned and made anew' (Kenway \& Holden, 2020, p. 7). Those standards are based upon the number of bedrooms a household 'needs', which in turn 'influences everything from the amount of social security payable to support 
housing costs to the core calculations of the capital's long term (20 year) housing requirement in the London Plan' (ibid.). Kenway \& Holden argue the standards are doubly flawed, because they do not allow enough bedrooms to allow self-isolation, and do not take into account the number of bathrooms in a household, another critical factor in self-isolation. Historical data from the English Housing Survey shows that 3 per cent of households in England are overcrowded, based on the UK Government housing standards noted above, with huge variations between ethnic groups $30 \%$ of Bangladeshi households experience overcrowding, compared to $15 \%$ for Black African, and $2 \%$ for White British (MHCLG, 2019).

Kenway \& Holden's research, along with these broader trends, were drawn upon in an article on the differential impacts of Covid-19 in the Observer newspaper, which included anecdotal testimony from several families living in single bedrooms in London, sharing bathrooms and kitchens with four other households (Wall, 2020). The father of one of these families was reported as saying "'I can hear some of my neighbours coughing all the time. It is really scary. I want to protect my family but what can I do?"' (p. 14). These conditions are distressingly similar to those in London and other cities that prompted the actions of Howard and other social reformers a century ago - note his reference to 'foul air' in the Town magnet above. The welfare states and interventionist governance regimes, including planning, which emerged over the first threequarters of the $20^{\text {th }}$ century to address such conditions have, in 2020, been subject to nearly fifty years of retrenchment under the ideology of neoliberalism. In the UK, particularly England, this has resulted in a situation where planning is seen as a barrier to economic growth and has thus been the focus of much deregulatory attention by successive governments (Lord \& TewdwrJones, 2014).

It is this de-regulated context which allows the prevalence of houses in multiple occupation criticised in the Observer article above, and positively encourages the conversion of offices into homes under "permitted development" rules with none of the scrutiny offered by the usual requirement to apply for planning permission. A recent study of the homes delivered through the permitted development route highlighted that it is 'leading to the development of very lowquality housing, sometimes in poor locations' (Clifford et al., 2019, p. 201). Only $30 \%$ of the housing units studied met national housing standards, $77 \%$ of them were studios or one-bedroom apartments, and only $14 \%$ of them had access to private or communal amenity space (Clifford et al., 2019), replicating Howard's 'closing out of nature' in the Town magnet. It seems clear that people would not choose to occupy such poor-quality accommodation if they had any choice, but as Clifford et al. note, in areas of high housing demand and for those in urgent need of housing, no such choice may be available - the 'high rents and prices' Howard decries in his Town magnet. The occupants of these types of homes will, one assumes, find self-isolation difficult, and the lack of access to amenity space will be particularly challenging under social distancing rules.

These extreme examples of deregulation are the exception rather than the rule, but there is a general tendency across parts of England towards higher density, smaller and more centrally located homes. This is of course a part of the wider trend towards the 'compact city', despite critiques of that approach (Neuman, 2005). In general, English planning policy encourages urban development over rural, building on brownfield over greenfield land, and city centre over suburban. These principles are not unique to England, and in many other parts of the world are used to great effect to produce high quality urban areas (see Figure 2).

[INSERT FIGURE 2 HERE] 
Figure 2 - Vauban, in Freiburg, Germany

Source: Poudougg - Own work, CC BY-SA 4.0, https://commons. wikimedia.org/w/index.php?curid $=56814284$

The type of development shown in Figure 2, much lauded by Professor Sir Peter Hall, is far from common in England. More typical is the construction of 'Rabbit Hutches on Postage Stamps' (Evans, 1991) in suburban and urban fringe areas, whilst in city centres a common feature in recent years has been the construction of a large number of high-density, privately built apartment blocks, typically for the lucrative "buy to rent" market (see Figure 3 for an example).

\section{[INSERT FIGURE 3 HERE]}

Figure 3-Newly built apartments in Manchester

Source: Dai O'Nysius, CC BY-SA 3.0, https://commons. wikimedia.org/w/index.php?curid=54218132

The first wave of this form of development took place prior to the 2008-onwards financial crash and recession, making up a large proportion of new homes being built at the time in cities such as Bristol, Birmingham, Leeds, Newcastle and Manchester (Boddy, 2007). As easy access to capital dried up, the quantity of apartments being built fell, but recent years have seen a second wave, with the student and young professional market driving much of the construction in cities like Liverpool (Couch \& Fowles, 2019).

Couch and Fowles (2019) situate this growth within a broader context of reurbanisation, including 'rising demand for city centre living, especially from young childless adult households' (p. 188), but note that the deregulation which is now a feature of planning in England has resulted in 'too many small apartments, few of which are well provided with the amenities necessary for anything other than short-term occupation by one- and two-person households' (ibid.). Such households, we can speculate, will currently be grappling with similar issues of social isolating and access to open space as those in the 'permitted development' homes discussed above. The transitory nature of the occupants of many of these apartments is another issue which the Covid-19 outbreak highlights. Anecdotally, colleagues of mine who live in the city centre of Liverpool have reported that many of the students and single person households who normally make that area their home have left, many to return to their parental home. This in turn means that supermarkets, etc. in the city centre have closed due to lack of custom, leaving those who remain with problems of access to day-to-day necessities. The conventional benefits of urban living, e.g. shorter commutes and immediate access to Howard's 'places of amusement', have evaporated and the disadvantages appear more acute. A key question for planning, and planners, is whether this will lead to changes in residential preference, and whether it should lead to changes in planning orthodoxy around high-density urban development.

\section{The People: Where Will They Go Now?}

In this Viewpoint I have suggested that the form which much housebuilding now takes in the UK is far from the 'Town-Country magnet' proposed by Ebenezer Howard in his landmark contribution of 1898. Howard sought to achieve 'a healthy, natural, and economic combination of town and country life' (1898, p. 13). There is very little of 'country life' in the converted office blocks and newly built apartments being constructed in British cities. This in itself is not a new observation the paradox that the planning 'profession's modern origins stem from responses to overcrowding', yet 'The classic response to [urban sprawl] has been compact settlements' (Neuman, 2005, p. 11) is reasonably well trodden ground. In this Viewpoint, however, I have highlighted the negative consequences of urban densification in terms of Covid-19 transmission 
and lack of access to open space. It is essential to point out at this point that a dense population does not, ipso facto, lead to higher rates of Covid-19. Many comparably or more dense countries than the UK, including the Netherlands, Hong Kong and Singapore, have seen much lower per capita rates of infection. Rather it seems that the UK's much criticised approach to containing and mitigating the virus has been exacerbated by a deregulated system of planning and building, placing the most vulnerable at acutely higher risk, and disadvantaging many who have little choice in where they live.

For households who have a choice, it seems possible that in coming months and years they might seek, in opposition to established planning doctrine, homes in suburban rather than city-centre locations; or perhaps rural rather than urban (Jones, 2020). This in turn will increase the price of homes in these locations, as they are, and will become more so, scarce commodities. If previous trends in home ownership and Planning continue, then it is likely that the 'spatial exclusion' (Sturzaker \& Shucksmith, 2011) which categorises many rural (and suburban) communities will become ever more acute, further privileging access to Ebenezer Howard's 'Beauty of Nature; Fields and Parks of Easy Access; Bright Homes \& Gardens'. This will, in my view, further increase the tension which has existed for planners since at least the 1970s - are we willing to continue to accept 'The Containment of Urban England' (Hall et al., 1973), when those negative consequences of that containment have been so starkly highlighted? 


\section{References}

BODDY, M. (2007) 'Designer Neighbourhoods: New-Build Residential Development in Nonmetropolitan UK Cities-The Case of Bristol', Environment and Planning A: Economy and Space, vol. 39, no. 1, pp. 86-105. D.O.I.: 10.1068/a39144

CABINET OFFICE (2020) Staying at home and away from others (social distancing) [Online], UK Government Cabinet Office, Available from:

https://assets.publishing.service.gov.uk/government/uploads/system/uploads/attachment data/file/876279/Full guidance on staying at home and away from others 1 .pdf (Accessed: 14 April 2020).

CLIFFORD, B., FERN, J., LIVINGSTONE, N. \& CANELAS, P. (2019) Understanding the Impacts of Deregulation in Planning: Turning Offices into Homes?, Palgrave Macmillan, Cham, Switzerland.

COUCH, C. \& FOWLES, S. (2019) 'Metropolitan Planning and the Phenomenon of Reurbanisation: The Example of Liverpool', Planning Practice \& Research, vol. 34, no. 2, pp. 184-205. D.O.I.: 10.1080/02697459.2018.1548237

EVANS, A. (1991) '"Rabbit Hutches on Postage Stamps": Planning, development and political economy', Urban Studies, vol. 28, no. 6, pp. 853-870.

HALL, P., GRACEY, H., DREWITT, R. \& THOMAS, R. (1973) The Containment of Urban England, Allen and Unwin, London.

HOWARD, E. (1898) To-Morrow: A Peaceful Path to Real Reform, Swann Sonnenschein, London.

JONES, R. (2020) Homebuyers 'plotting move to country' amid increased home working [Online], The Guardian, Available from:

https://www.theguardian.com/money/2020/may/08/homebuyers-plotting-move-tocountry-amid-increased-home-working (Accessed: 8 May 2020).

KENWAY, P. \& HOLDEN, J. (2020) Accounting for the Variation in the Confirmed Covid-19 Caseload across England: An analysis of the role of multi-generation households, London and time [Online], New Policy Institute, Available from:

https://www.npi.org.uk/files/2115/8661/6941/20-04-

11_Accounting_for_the_variation_in_Covid_cases_across_England.pdf (Accessed: 14 April 2020).

LORD, A. \& TEWDWR-JONES, M. (2014) 'Is Planning "Under Attack"? Chronicling the Deregulation of Urban and Environmental Planning in England', European Planning Studies, vol. 22, no. 2, pp. 345-361. D.O.I.: 10.1080/og654313.2012.741574

MHCLG (2019) Overcrowded households [Online], Ministry of Housing, Communities and Local Government, Available from: https://www.ethnicity-facts-

figures.service.gov.uk/housing/housing-conditions/overcrowded-households/latest (Accessed: 14 April 2020).

NEUMAN, M. (2005) 'The Compact City Fallacy', Journal of Planning Education and Research, vol. 25 , no. 1, pp. 11-26.

PIDD, H. \& DODD, V. (2020) UK police use drones and roadblocks to enforce lockdown [Online], The Guardian, Available from: https://www.theguardian.com/world/2020/mar/26/uk-policeuse-drones-and-roadblocks-to-enforce-lockdown (Accessed: 14 April 2020).

STURZAKER, J. \& SHUCKSMITH, M. (2011) 'Planning for housing in rural England: Discursive power and spatial exclusion', Town Planning Review, vol. 82, no. 2, pp. 169-193.

THOMAS, J. (2020) Cars to be stopped by Merseyside Police after force gets reports of lockdown house parties [Online], Liverpool Echo, Available from: 
https://www.liverpoolecho.co.uk/news/liverpool-news/cars-stopped-merseyside-policeafter-18069621 (Accessed: 14 April 2020).

WALL, T. (2020) Two adults, five children, one room: 'It's really scary, but what can I do?', The Observer, 12 April 2020, pp. 14-15. 